\title{
Editorial
}

\section{Special Issue: Thermal Analysis of Materials}

\author{
Sergey V. Ushakov $1, *(\mathbb{D})$ and Shmuel Hayun $2, *$ (i) \\ 1 School of Molecular Sciences and Center for Materials of the Universe, Arizona State University, \\ Tempe, AZ 85287, USA \\ 2 Department of Materials Engineering at the Ben-Gurion University of the Negev, Beer-Sheva 84105, Israel \\ * Correspondence: sushakov@asu.edu (S.V.U.); hayuns@bgu.ac.il (S.H.)
}

Citation: Ushakov, S.V.; Hayun, S. Special Issue: Thermal Analysis of Materials. Materials 2021, 14, 4923. https://doi.org/10.3390/ma14174923

Received: 12 August 2021

Accepted: 27 August 2021

Published: 30 August 2021

Publisher's Note: MDPI stays neutral with regard to jurisdictional claims in published maps and institutional affiliations.

Copyright: (c) 2021 by the authors. Licensee MDPI, Basel, Switzerland. This article is an open access article distributed under the terms and conditions of the Creative Commons Attribution (CC BY) license (https:/ / creativecommons.org/licenses/by/ $4.0 /)$.
The measurement of any physical property as a function of temperature brings the method used into the realm of thermal analysis. This makes "Thermal Analysis of Materials" a broad interdisciplinary subject. This Special Issue combines contributions solicited by editors that reflect their scientific interests and networks, with general related submissions received over two years. It contains 16 articles and 1 short review submitted by authors from 10 countries.

In several papers, well-established techniques of differential thermal analysis, thermogravimetry, and gas adsorption calorimetry are applied to research related to environmental problems, such as capturing $\mathrm{CO}_{2}$ from industrial processes by calcium looping [1]; the utilization of copper tailing wastes as an addition to Portland cement [2]; the reuse of soda lime $\mathrm{CO}_{2}$ absorbent in spacecrafts, submarines, anesthetics, and diving apparatuses [3]; and the passive fire protection offered by inorganic material-based insulation [4].

Another set of papers deals with the development of new or application-specific approaches, namely laser interferometry techniques for high precision measurements on non-standard samples, such as composite truss structures [5]; measurements of high temperature compressive creep in spark plasma sintering apparatuses [6]; measurements of the density of liquid oxides with aero-acoustic levitators [7]; and the simultaneous estimation of thermal conductivity and heat capacity in metal alloys [8].The range of materials covered includes polymers [9,10]; natural complex inorganic materials, such as natural sorbents [1] and industrial-grade thermal insulation [4]; single phase ceramic materials, such as spinel $\mathrm{MgAl}_{2} \mathrm{O}_{4}$ [11], rare earth sesquioxides [12], and double perovskite cobaltites [13]; metals, alloys, and intermetallic compounds [8,14-16].

The use of thermal analysis techniques to elucidate phase transformation kinetics can be found in papers on the hydration of cement [2] and in the study of microstructural evolutions in high-carbon and chromium-bearing steel [15]. A review by Plota and Masek [10] is devoted to the extrapolation of kinetic data on polymers' degradation for lifetime predictions. A paper by Frock et al. [16] provides a new method to study kinetics at heating rates between 5 and $1000 \mathrm{~K}$ per second. These heating rates are relevant to welding and laser melting processing but too fast for conventional differential scanning calorimeters and too slow for fast-scanning chip calorimetry. Examples of the applications of thermal analysis and calorimetry techniques to obtain thermodynamic data vary from measurements of enthalpies of water adsorption on defect spinel surfaces [11] to phase transformation enthalpies and entropies above $2000^{\circ} \mathrm{C}$ in rare earth oxides [12].

Thermal analysis contributes to the calculation of phase diagrams (CALPHAD), both through experimental phase diagrams and by providing thermodynamic data for optimizations. Krishon et al. [17] extend the CALPHAD approach by calculating pressure dependence of several binary metal phase diagrams based on the temperature dependence of sound velocity and density data in liquid alloys. Thus, this Special Issue provides a sampling of the current use, diversity, and ongoing developments of techniques and approaches in the thermal analysis of materials. 
Conflicts of Interest: The authors declare no conflict of interest.

\section{References}

1. Labus, K. Comparison of the Properties of Natural Sorbents for the Calcium Looping Process. Materials 2021, 14, 548. [CrossRef] [PubMed]

2. Liu, S.; Li, Q.; Zhao, X. Hydration Kinetics of Composite Cementitious Materials Containing Copper Tailing Powder and Graphene Oxide. Materials 2018, 11, 2499. [CrossRef] [PubMed]

3. Rogalewicz, B.; Czylkowska, A.; Anielak, P.; Samulkiewicz, P. Investigation and Possibilities of Reuse of Carbon Dioxide Absorbent Used in Anesthesiology. Materials 2020, 13, 5052. [CrossRef] [PubMed]

4. Gunnarshaug, A.; Metallinou, M.M.; Log, T. Study of Industrial Grade Thermal Insulation at Elevated Temperatures. Materials 2020, 13, 4613. [CrossRef] [PubMed]

5. Luo, W.; Xue, S.; Zhao, C.; Zhang, M.; Li, G. Robust Interferometry for Testing Thermal Expansion of Dual-Material Lattices. Materials 2020, 13, 313. [CrossRef] [PubMed]

6. Ratzker, B.; Kalabukhov, S.; Frage, N. Spark Plasma Sintering Apparatus Used for High-temperature Compressive Creep Tests. Materials 2020, 13, 396. [CrossRef] [PubMed]

7. Ushakov, S.V.; Niessen, J.; Quirinale, D.G.; Prieler, R.; Navrotsky, A.; Telle, R. Measurements of Density of Liquid Oxides with an Aero-Acoustic Levitator. Materials 2021, 14, 822. [CrossRef] [PubMed]

8. Dos Santos Carollo, L.F.; de Lima e Silva, A.L.F.; de Lima e Silva, S.M.M. A Different Approach to Estimate TemperatureDependent Thermal Properties of Metallic Materials. Materials 2019, 12, 2579. [CrossRef] [PubMed]

9. Wang, Z.; Wei, R.; Wang, X.; He, J.; Wang, J. Pyrolysis and Combustion of Polyvinyl Chloride (PVC) Sheath for New and Aged Cables via Thermogravimetric Analysis-Fourier Transform Infrared (TG-FTIR) and Calorimeter. Materials 2018, $11,1997$. [CrossRef] [PubMed]

10. Plota, A.; Masek, A. Lifetime Prediction Methods for Degradable Polymeric Materials-A Short Review. Materials 2020, 13, 4507. [CrossRef] [PubMed]

11. Mordekovitz, Y.; Shoval, Y.; Froumin, N.; Hayun, S. Effect of Structure and Composition of Non-Stoichiometry Magnesium Aluminate Spinel on Water Adsorption. Materials 2020, 13, 3195. [CrossRef] [PubMed]

12. Ushakov, S.V.; Hayun, S.; Gong, W.; Navrotsky, A. Thermal Analysis of High Entropy Rare Earth Oxides. Materials $2020,13,3141$. [CrossRef] [PubMed]

13. Szpunar, I.; Strandbakke, R.; Sørby, M.H.; Wachowski, S.L.; Balaguer, M.; Tarach, M.; Serra, J.M.; Witkowska, A.; Dzik, E.; Norby, T.; et al. High-Temperature Structural and Electrical Properties of $\mathrm{BaLn} \mathrm{Co}_{2} \mathrm{O}_{6}$ Positrodes. Materials 2020, 13, 4044. [CrossRef] [PubMed]

14. Kim, K.; Kim, D.; Park, K.; Cho, M.; Cho, S.; Kwon, H. Effect of Intermetallic Compounds on the Thermal and Mechanical Properties of Al-Cu Composite Materials Fabricated by Spark Plasma Sintering. Materials 2019, 12, 1546. [CrossRef] [PubMed]

15. Wang, F.; Qian, D.-S.; Xiao, P.; Deng, S. Accelerating Cementite Precipitation during the Non-Isothermal Process by Applying Tensile Stress in GCr15 Bearing Steel. Materials 2018, 11, 2403. [CrossRef] [PubMed]

16. Fröck, H.; Reich, M.; Milkereit, B.; Kessler, O. Scanning Rate Extension of Conventional DSCs through Indirect Measurements. Materials 2019, 12, 1085. [CrossRef] [PubMed]

17. Kirshon, Y.; Ben Shalom, S.; Emuna, M.; Greenberg, Y.; Lee, J.; Makov, G.; Yahel, E. Thermophysical Measurements in Liquid Alloys and Phase Diagram Studies. Materials 2019, 12, 3999. [CrossRef] [PubMed] 